\title{
Identitas Kota : Pembangunan Imaji Kota melalui Karya Seni di Ruang Publik
}

\author{
Budi Adi Nugroho ${ }^{1}$, Setiawan Sabana ${ }^{2}$, Tisna Sanjaya ${ }^{3}$ \\ ${ }^{1,2,3}$ Program Studi Doktor Ilmu Seni Rupa dan Desain \\ Fakultas Seni Rupa dan Desain \\ Institut Teknologi Bandung
}

\begin{abstract}
City has a character that reflects the inhabitants and idealism of leaders who try to shape the image of their city. Imagery or images would later describe a city as a whole in a certain picture that put the city in the scale from the smallest to global regions. The control upon its image is carried out with image management that appears in the front corridors of the city, as is done by the City of Bandung in building the image of the city as a positioning strategy for the part of the world's creative and design cities. The research method will use interdisciplinary research, involving anthropological approaches, material exploration, and fine art works. Public understanding, decision makers up to the capital are needed in supporting the development of the image of the city. The level of importance in understanding the work of art in the public space as one component that can help build the image of the city of Bandung. This research will produce work proposals that can help support the overall image of the city of Bandung that is integrated with the character and development of the city.
\end{abstract}

Keywords: city, identity, management, Bandung, space, public art

\section{Pendahuluan}

Kota sebagai pusat, layaknya magnet yang menarik sekitarnya, menjadikan ruang tak sebatas pencakar langit ataupun kepadatan material semata. Inilah anggapan umum terhadap kota, beberapa citra lingkungan pada kota diantaranya terbentuk melalui legibilitas, persepsi, struktur, dan identitas.
Dengan legibilitas, membaca sensasi visual melalui warna, bentuk, suara, bau dan lainnya ditangkap oleh pengamat untuk membentuk citra lingkungannya.

Selanjutnya, Identitas sebagai bentuk identifikasi terhadap suatu objek. Untuk struktur sendiri merupakan bagian pembentukan pola spasial dan relasi antara pengamat dengan 
ruang. Terakhir arti dan makna didapat secara praktis dan emosional oleh pengamat kota.

Melalui buku 'The Image of The City' yang ditulis oleh Kevin Lynch melalui analisa terhadap gambaran publik pada kota menyimpulkan lima komponen pembentuk citra kota: paths(jalan/akses), edges (ujung/batas), district (wilayah), node (titik simpang), dan landmark (tanda wilayah).

Paths atau jalur menjelma menjadi elemen kota paling utama. Masyarakat berpikir terhadap kota melalui kondisi topografi, alur, luas, maupun jalur dari suatu wilayah. Pengamat yang memahami akan tahu jalur di kota secara tepat terkhusus pada hubungan antara jalur sepanjang jalannya. Elemen ini berbicara soal akses atau medium yang dilalui penghuni untuk menuju satu tempat dari tempat lainnya. Manusia sebagai pengamat menjadikan jalan sebagai ruang dan akses untuk bergerak. Dalam hal ini jalur (Paths) bisa berupa trotoar, bahu jalan, jalan raya, halte, saluran, jalan tol, jalur bis, jalur sepeda, maupun jalur kereta. Bagi sebagian orang pengaruh jalan sangat erat dengan pembentukan persepsi kota tersebut. Marco Kusumawijaya juga pernah menuliskan bahwa nama jalan adalah salah satu kunci pembuka ke kedalaman pemahaman akan riwayat sebuah tempat.

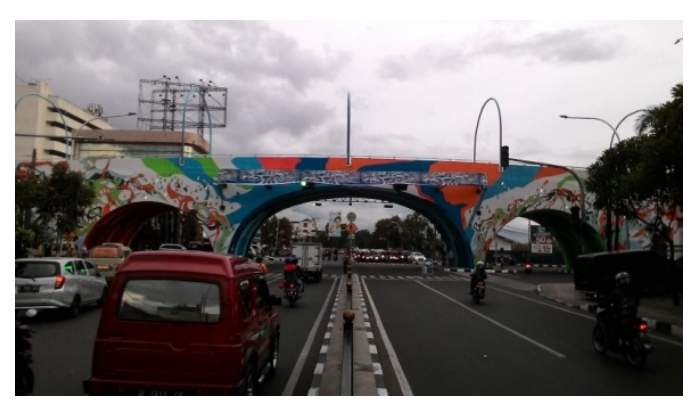

Gambar 1.1 Foto jembatan 'Pelangi' dari arah Utara

Jembatan layang 'Pelangi' yang berada di perempatan Jl. Antapani, Jl.Kiaracondong dan Jl. Jakarta menjadikannya sebagai contoh elemen batas di Kota Bandung yang akan memudahkan menggambarkan ruang pada peta melalui baris di setiap batasnya, contoh lain berupa mural atau grafiti yang berada di Jl. Siliwangi. Elemen yang paling melekat pada simbol suatu kota dan yang tak bisa dipisahkan dari pembentukan kesan kota adalah Landmark. Elemen ini biasa dijadikan simbol, tanda, maupun ciri dari riwayat kejadian kota. Landmark bisa terbentuk dari beragam tanda, huruf pada toko, monumen, pohon, pintu, patung, tugu, maupun bangunan megah sekalipun. Hal ini yang akan paling memberikan kesan dan makna kota terhadap pengamat. Renovasi sejumlah taman yang dilakukan oleh walikote periode 2013-2017 Ridwan Kamil menjadi landmark baru bagi warga Kota Bandung.

Sejarah terbentuknya kota ini dapat mempermudah menggambarkan perkembangan maupun perubahan imaji kota yang ada didalamnya. 
Berbeda dengan konsep kota-kota di Eropa yang mengalami transformasi karena pengaruh teknologi dan industrialisme, maka konsep kota di Indonesia jauh lebih kompleks. Konsep kuta-negara sebagai kumpulan wilayah kampung yang otonom dengan penguasa kampung. Konsep kolonialisme yang ada memerlukan infrastruktur pendukung untuk memperlancar upaya tersebut, sistem jalan, kota, transportasi, pembagian peruntukan wilayah dan pengaturan lainnya menyebabkan kampung dan kerajaan berubah menjadi sistem kota awal. Bersinggungan dengan wilayah kampung yang ada sebelumnya dan menciptakan daerah antara yang sering disebut sebagai kampung kota. Kampung kota adalah wilayah yang berada ataupun wilayah yang berbatasan langsung di antara wilayah kampung dan kota. Kampung kota memiliki karakteristik unik hingga saat ini, ketika perkembangan kota lebih banyak diatur untuk melalui modal kapital, maka penghuni kampung asli akan bertahan, menyesuaikan diri. Kampung kota tidak berubah menjadi kota dan tetap menjadi bagian dari kota hingga terdapat kemungkinan sebagian di antaranya dengan faktor tambahan tertentu seperti politik dan sejarah berubah menjadi kota metropolis, kampung kota di Jawa pada awalnya membaurkan antara pendatang dari barat, kaum pribumi dan kelompok warga lainnya, secara fisik kampung kota dapat dengan mudah diamati dengan keberadaannya di balik gedung-gedung modern yang menjulang, terus hidup dan berkembang biak dengan memanfaatkan sempitnya lahan.

Kota yang dibentuk oleh kolonial memiliki karakteristik yang berbeda, kota Bandung merupakan wilayah yang ditunjuk untuk dijadikan wilayah dengan konsep tertentu seperti kota administratif, kota peristirahatan ataupun kota industri. Bandung adalah salah satu kota dengan klasifikasi ini, Belanda melalui Raffles memutuskan untuk membangun kota peristirahatan di sebuah area yang dikelilingi pegunungan dan memiliki suhu seperti di negara mereka. Bandung berkembang menjadi daerah permukiman dan berkembang menuju formasi idealnya dalam perkembangan. Konsep kota peristirahatan yang dibuat menghadirkan struktur kota yang berbeda dengan struktur kota seperti Jakarta yang diutamakan sebagai kota administratif.

\section{LANDASAN TEORI}

Dalam memahami imaji kota perlu diketahui beberapa pengertian imaji kota, elemen-elemen pembentuk imaji kota, faktor-faktor yang mempengaruhi pembentukan imaji kota dan metode identifikasi imaji kota. Menurut kamus Umum Bahasa Indonesia (1987), kata imaji itu sendiri mengandung arti: rupa, 
gambar, gambaran, gambaran yang dimiliki orang banyak mengenai pribadi,

perusahaan/organisasi/produk.

Dapat juga diartikan sebagai kesan mental atau bayangan visual yang ditimbulkan oleh sebuah kota. Dengan demikian secara harfiah imaji kota dapat diartikan sebagai kumpulan dari interaksi sensorik langsung seperti diimplementasikan melalui sistem nilai pengamat dan diakomodasikan kedalam penyimpanan memori dimana input dari sumber tak langsung sama pentingnya (Pocock \& Hudson, 1978).

Imaji secara luas terkait dengan ruang, dan dapat pula dikaitkan dengan rasa atau persepsi seseorang. Berikut ini merupakan beberapa karakteristik dari sebuah imaji (Pocock \& Hudson, 1978),

- Imaji merupakan sebagai representasi parsial dan sederhana.

- Imaji umumnya skematis atau dibentuk secara fisik atau sosial. Objek yang menimbulkan imaji tersebut tidak perlu memiliki bentuk yang sama terhadap lingkungannya.

- Imaji merupakan "Idiosyncratic" atau dengan kata lain setiap orang akan memiliki respon atau imaji yang berbeda terhadap sesuatu hal yang sama.

Dari penjelasan tersebut dapat disimpulkan bahwa imaji sangat tergantung pada persepsi atau cara pandang orang masing-masing. Imaji juga berkaitan dengan hal-hal fisik. Imaji kota sendiri dapat diartikan sebagai gambaran mental dari sebuah kota sesuai dengan rata-rata pandangan masyarakatnya (Zahnd, 1999). Imaji kota mengambarkan suatu persamaan dari sejumlah gabungan atau satuan informasi yang dihubungkan dengan tempatnya (Kotler, 1993). Diterjemahkan melalui gambaran mental dari sebuah kata sesuai dengan rata-rata pandangan masyarakatnya (Lynch, 1982).

Sebuah imaji lingkungan (kota) menurut (Lynch, 1982) dalam bukunya "Image of the city" dapat dianalisis kedalam komponen yang meliputi:

- Identitas, suatu objek harus dapat dibedakan dengan objek-objek lain sehingga dikenal sebagai sesuatu yang berbeda atau mandiri.

- Struktur, imaji harus meliputi hubungan spasial atau hubungan pola imaji objek dengan pengamat dan dengan objek-objek lainnya.

- Makna, yaitu suatu objek harus mempunyai arti tertentu bagi pengamat baik secara kegunaan maupun emosi yang ditimbulkan.

2.1. Elemen-elemen Pembentuk Imaji Kota

Imaji kota menurut Lynch (1982) terbentuk dari elemen-elemen 
pembentuk citra kotanya yang terdiri dari:

1. Tetenger (Landmark), yang merupakan titik referensi seperti elemen simpul tetapi tidak masuk kedalamnya karena bisa dilihat dari luar letaknya. Tetenger adalah elemen eksternal yang merupakan bentuk visual yang menonjol dari kota misalnya gunung, bukit, gedung tinggi, menara, tanah tinggi, tempat ibadah, pohon tinggi dan lain-lain. Beberapa tetenger letaknya dekat sedangkan yang lain jauh sampai diluar kota. Tetenger adalah elemen penting dari bentuk kota karena membantu orang untuk mengenali suatu daerah.

2. Jalur (Path), yang merupakan elemen paling penting dalam citra kota. Kevin Lynch menemukan dalam risetnya bahwa jika identitas elemen ini tidak jelas, maka kebanyakan orang meragukan imaji kotanya secara keseluruhan. Jalur merupakan alur pergerakan yang secara umum digunakan oleh manusia seperti jalan, gang-gang utama, jalan transit, lintasan kereta api, saluran dan sebagainya. Jalur mempunyai identitas yang lebih baik jika memiliki tujuan yang besar (misalnya ke stasiun, tugu, alun-alun) serta ada penampakan yang kuat (misalnya pohon) atau ada belokan yang jelas.

3. Kawasan (District), yang merupakan kawasan-kawasan kota dalam skala dua dimensi. Sebuah kawasan memiliki ciri khas mirip (bentuk, pola dan wujudnya) dan khas pula dalam batasnya, dimana orang merasa harus mengakhiri atau memulainya. Kawasan dalam kota dapat dilihat sebagai referensi interior maupun eksterior. Kawasan menpunyai identitas yang lebih baik jika batasnya dibentuk dengan jelas berdiri sendiri atau dikaitkan dengan yang lain.

4. Simpul (Nodes), yang merupakan simpul atau lingkaran daerah strategis dimana arah atau aktivitasnya saling bertemu dan dapat diubah arah atau aktivitasnya misalnya persimpangan lalu lintas, stasiun, lapangan terbang, dan jembatan. Kota secara keseluruhan dalam skala makro misalnya pasar, taman, square dan lain sebagainya. Simpul adalah suatu tempat dimana orang mempunyai perasaan masuk dan keluar dalam tempat yang sama.

5. Batas atau tepian (Edge), yang merupakan elemen linier yang tidak dipakai atau dilihat sebagai jalur. Batas berada diantara dua kawasan tertentu 
dan berfungsi sebagai pemutus linier misalnya pantai, tembok, batasan antara lintasan kereta api, topografi dan lain-lain. Batas lebih bersifat sebagai referensi daripada misalnya elemen sumbu yang bersifat koordinasi (linkage). Batas merupakan penghalang walaupun kadang-kadang ada tempat untuk masuk. Batas merupakan pengakhiran dari sebuah kawasan atau batasan sebuah kawasan dengan yang lainnya. Demikian pula fungsi batasnya harus jelas membagi atau menyatukan.

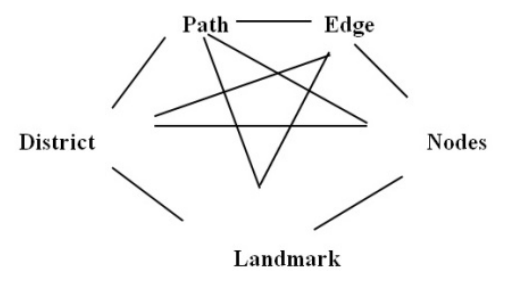

Gambar 2.1 Formulasi Elemen Imaji Kota Menurut Lynch (1982)

\section{Metode Penelitian}

Karya seni yang akan dihadirkan berkaitan erat dengan makna ruang, waktu, dan sudut pandang penghuni ruang dan waktu tersebut maka etnografi akan dijadikan sebuah acuan untuk penciptaan karya yang terkait erat dengan interpretasi atau pembacaan/pemaknaan karya dan persepsi dari seniman dan publiknya dalam memahami karya seni dan ruangnya. Etnografi akan membantu membaca metoda penciptaan karya terutama dalam memaknai, mendefinisi dan menginterpretasi melalui sudut pandang pemikirannya.

Pengidentifikasian faktor yang mempengaruhi persepsi masyarakat dalam pemilihan elemen pembentuk imaji kota dan elemen imaji kota baru perlu dilakukan dengan mengunakan pendekatan atau metode imaji kota yang sudah ada. Elemen-elemen fisik pembentuk imaji kota baru diketahui dengan jawaban pertanyaan responden sedangkan faktor-faktor yang mempengaruhi persepsi masyarakat dalam pemilihan elemen pembentuk imaji kota diketahui dari karakteristik masyarakatnya yang merupakan bagian dari faktor internal dan juga mengidentifikasi faktor eksternal yang juga ikut mempengaruhi persepsi masyarakat. Dengan demikian dapat diketahui apakah elemen yang berkesan menimbulkan perasaan yang positif lalu responden juga ditanya mengenai elemen-elemen fisik yang mereka sukai beserta alasannya.

Tabel 3.1 Elemen Pembentuk Imaji Kota

\begin{tabular}{|c|c|c|}
\hline $\begin{array}{l}\text { Variabel } \text { (Elemen- } \\
\text { elemen pembentuk } \\
\text { imaji kota) }\end{array}$ & $\begin{array}{l}\text { Berdasarka } \\
\text { n Teori }\end{array}$ & Keterangan \\
\hline $\begin{array}{l}\text { 1. Jalur/path } \\
\text { 2. Batas atau tepian /edge } \\
\text { 3. Kawasan/district }\end{array}$ & $\begin{array}{l}\text { Kevin } \\
\text { Lynch }\end{array}$ & $\begin{array}{l}\text { Disadur dari } \\
\text { buku "Image } \\
\text { of the city" }\end{array}$ \\
\hline
\end{tabular}




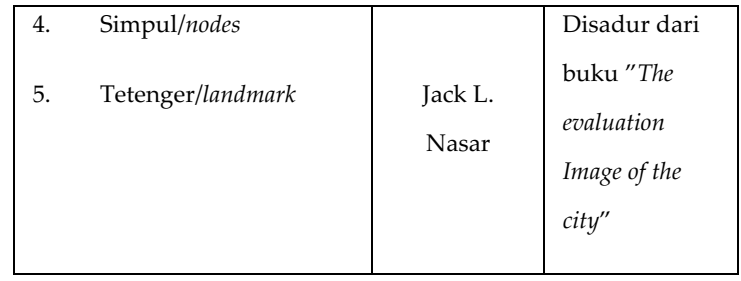

Sumber: Kevin Lynch, 1982 dan Jack L.Nasar, 1998

Tabel 3.2 Faktor-Faktor Yang Mempengaruhi Persepsi Masyarakat

\begin{tabular}{|c|c|c|}
\hline $\begin{array}{l}\text { Variabel (Faktor yang } \\
\text { berpengaruh terhadap } \\
\text { terbentuknya imaji kota) }\end{array}$ & $\begin{array}{l}\text { Berdasarkan } \\
\text { Teori }\end{array}$ & Keterangan \\
\hline $\begin{array}{l}\text { 1. Persepsi masyarakat } \\
\text { mengenai elemen- } \\
\text { elemen pembentuk } \\
\text { imaji kota (landmark, } \\
\text { edge, districk, nodes, dan } \\
\text { path) } \\
\text { (penghuni/pengunjung) } \\
\text { 2. Waktu pengamatan } \\
\text { masyarakat } \\
\text { (berdasarkan lama } \\
\text { tinggal untuk penghuni } \\
\text { dan pengalaman } \\
\text { berkunjung/frekuensi } \\
\text { kunjungan untuk } \\
\text { pengunjung) } \\
\text { 3. Posisi pengamat } \\
\text { (dibedakan menurut } \\
\text { lokasi tempat tinggal) }\end{array}$ & $\begin{array}{l}\text { Kevin Lynch } \\
\text { dan Philip } \\
\text { Kotler }\end{array}$ & $\begin{array}{l}\text { Teory Kotler } \\
\text { lebih } \\
\text { menekankan } \\
\text { pada teori } \\
\text { marketing } \\
\text { place } \\
\text { dimana } \\
\text { faktor } \\
\text { penting } \\
\text { dalam } \\
\text { memasarkan } \\
\text { kota adalah } \\
\text { menciptakan } \\
\text { imaji kota }\end{array}$ \\
\hline
\end{tabular}

Sumber: Kevin lynch, 1982 dan Philip Kotler, 1993

Tabel 3.3 Metode Identifikasi Imaji Kota

\begin{tabular}{|l|l|l|}
\hline Metode & Berdasarkan & Keterangan \\
Kontifikasi imaji & Teori & \\
\hline
\end{tabular}

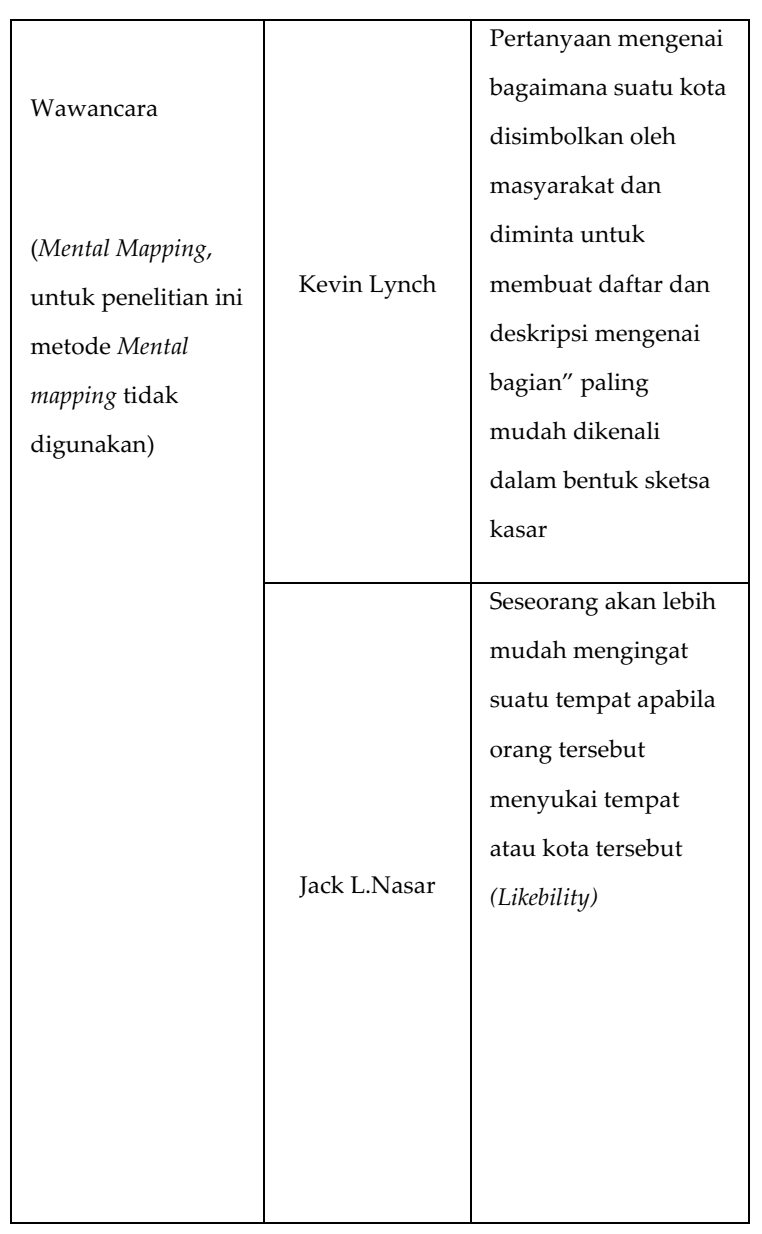

Sumber: Kevin lynch, 1982 dan Jack L.Nasar, 1998

\section{Presentasi Data}

Metode diatas digunakan untuk mengidentifikasi imaji yang dapat dibentuk pada suatu kota, sebagai contoh kasus akan digunakan di kota Bandung sebagai studi identifikasi kota berdasarkan elemen-elemen kota, faktor yang berpengaruh, dan pemetaan mental. Wilayah jalan Ir. H. Djuanda atau yang lebih dikenal sebagai area Dago adalah area kota baru yang berkembang sejak akhir 90an hingga saat ini, pusat kota yang ditandai dengan adanya alun-alun pada sebuah kota, mengalami pergeseran pada kasus ini. Perkembangan wilayah Dago ditandai dengan merebaknya pusat busana dan kuliner di wilayah 
tersebut, menjadikan Dago sebagai sentra baru di Kota Bandung setelah wilayah Alun-alun.

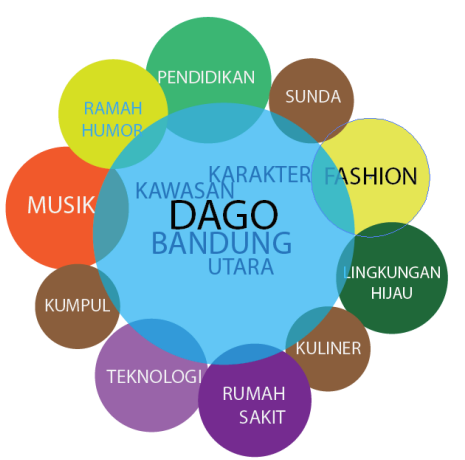

Tabel 4.1 Metode pembentukan imaji kota

Pemetaan tentang kedinamisan interaaksi ruang, publik dan karakter yang terjadi di area Dago coba dipetakan dalam diagram diatas, gabungan antara fungsi ruang, karakter publik dan pemetaan mental menjadi bagian didalamnya. Karakter area tersebut dimasukan dalam studi kasus ini disebut sebagai karakter Bandung Utara dikarenakan letak geografis wilayah tersebut di Kota Bandung. Melalui pemetaan ini maka pembentukan imaji kota dapat dilakukan berdasarkan pada panduan satu atau gabungan beberapa karakter ruang dan publik pada wilayah tersebut. Panduan yang dipetakan dalam diagram diatas menjadi panduan dalam membaca karakter ruang, karakter publik yang mengisi ruang tersebut dan interaksi yang terjadi diantara keseluruhan elemen yang terintegrasi dengan pemetaan.
Panduan yang dipetakan dalam area tersebut kemudian dipecah kedalam beberapa area bagian yang lebih kecil untuk mempermudah pembacaan karakter ruang dan publik, sehingga mampu menghasilkan karakter karya yang tepat, ruang yang lebih kecil di petakan menjadi titik-titik lokasi yang tepat untuk menempatkan karya seni. Pemetaan titik-titik lokasi pada studi kasus ini dibagi menjadi 6 bagian yang ditentukan berdasar elemen batas, simpul, jalur dan landmark, yaitu Area Simpang Dago - Jalan Dayang Sumbi, Jalan Dayang Sumbi Jalan Teuku Umar, Jalan Teuku Umar - Jalan Hasanudin, Jalan Hasanudin - Area fly over Cikapayang, Area fly over Cikapayang _ Jalan Ranggamalela, Jalan Ranggamalela - Jalan R.E Martadinata dalam peta titik sebagai berikut:

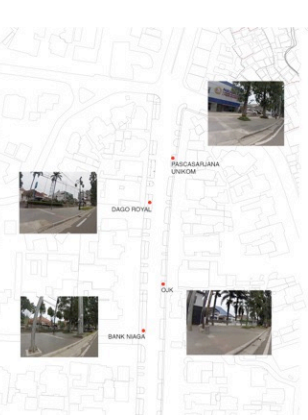

Gambar 4.1 Pemetaan karakter ruang dan publik pada batasan area Simpang dago hingga Jalan Taman Sari 
Area Simpang Dago hingga persimpangan antara Jl. Ir. $\mathrm{H}$. Djuanda dan Jl. Taman Sari merupakan kawasan bisnis seperti bank (Niaga, Bisnis), hotel (Dago Royal), pendidikan (Pasca Sarjana Unpad) dan perkantoran (OJK). Pada area ini diteukan 4 lokasi yang memiliki karateristik ruang yang layak untuk penempatan karya seni yang membangun imaji kota Bandung dengan tema lingkungan alam kota Bandung.

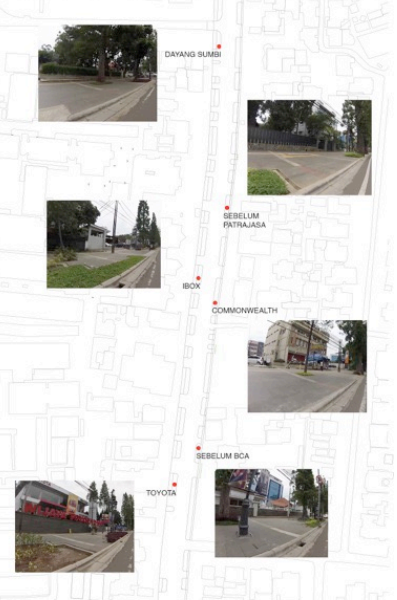

Gambar 4.2 Pemetaan karakter ruang dan publik pada batasan Jalan Dayang Sumbi hingga Jalan Teuku Umar

Pada area ini terdapat 5 titik lokasi yang dapat diolah, diantara ruangruang yang banyak diisi hotel (Patra Jasa), bank (Commonwealth, BCA), komersial (EF, swalayan, SPBU)

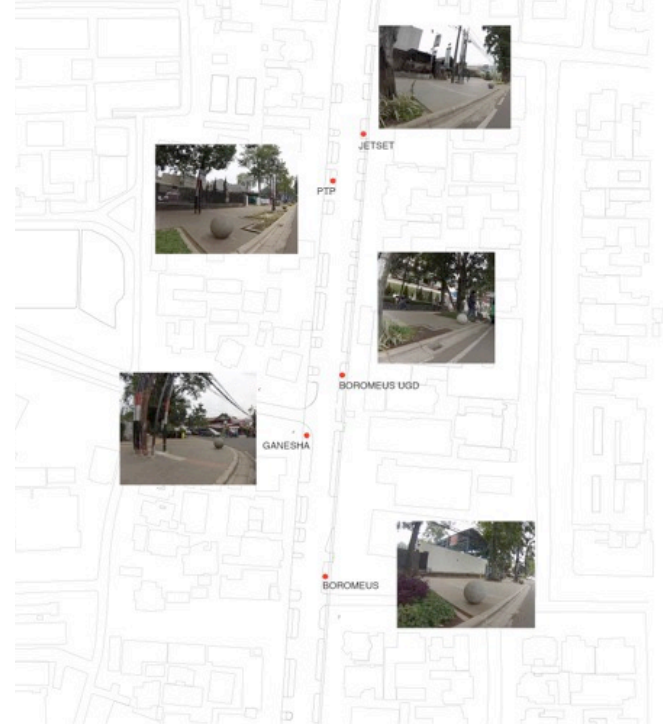

Gambar 4.3 Pemetaan karakter ruang dan publik pada batasan Jalan Teuku Umar hingga Jalan Hasanudin

Area ini lebih dominan karakter ruang bisnis (busana), pendidikan (ITB, Unpad) dan jasa (rumah sakit) sehingga tema yang diterapkan di area ini seputar pendidikan, kesehatan dan hiburan.

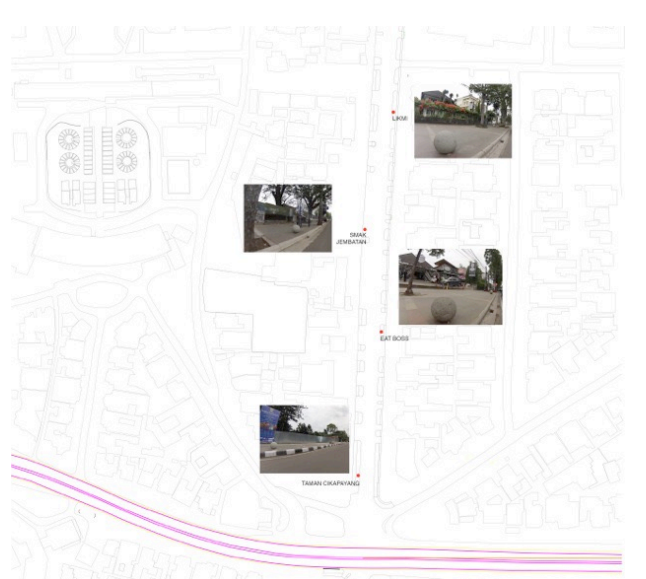

Gambar 4.4 Pemetaan karakter ruang dan publik pada batasan Jalan Teuku Umar hingga area di bawah fly over Cikapayang 
Pada area ini terdapat 4 titik lokasi yang cukup luas untuk menggambarkan tema yang berkaitan dengan hiburan yang amat kuat di area ini. Beberapa factory outlet, restoran, cafe,dan pusat oleh-oleh menjadikan area ini salah satu tujuan utama bagi wisatawan.

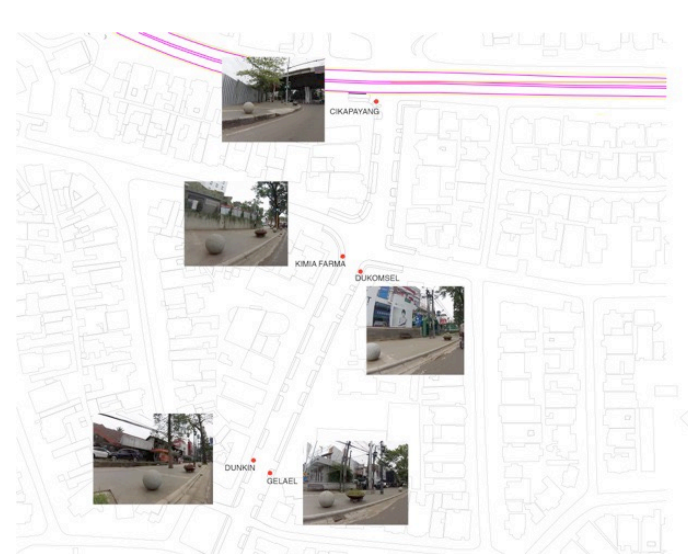

Gambar 4.5 Pemetaan karakter ruang dan publik pada batasan area di bawah fly over Cikapayang hingga Jalan Ranggamalela

Kawasan yang penuh dengan pusat perniagaan, hotel, serta restoran membuat area ini aktif sepanjang hari kerja, banyaknya perkantoran yang berlokasi di area ini menyebabkan jumlah pekerja yang menghabiskan waktu di area ini lebih tinggi dibanding area lainnya.

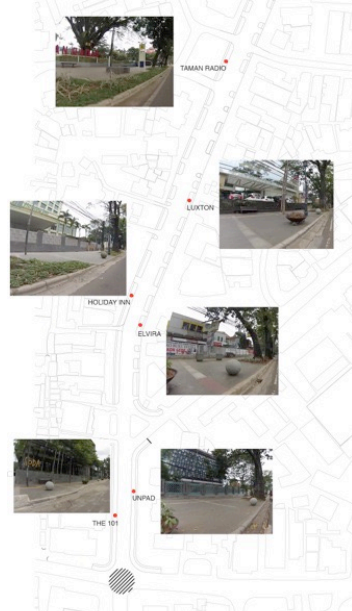

Gambar 4.6 Pemetaan karakter ruang dan publik pada batasan Jalan Ranggamalela Cikapayang hingga Jalan R.E Martadinata

Pada area ini kesibukan yang terlihat nampak dari padatnya kendaraan yang melintas, namun jumlah pejalan kaki pada hari kerja jauh berbalik dibanding akhir pekan. Hotel, rumah sakit, pusat pendidikan yang bersebelahan dengan salah satu pusat budaya busana lokal menjadikan area ini memiliki kedinamisan yang berbeda dibanding area lain, dipengaruhi pula oleh keberadaan dua pusat perbelanjaan besar yang terletak di bagian ujung selatan area. 5 titik lokasi dalam pemetaan memiliki karakter yang tepat untuk dijadikan ruang kreasi bagi karya seni.

\section{Kesimpulan}

Dengan memahami karakter sebuah ruang melalui pengamatan mendalam terhadap jalur, batas, kawasan, simpul dan penanda ruang yang ada, maka penataan sebuah ruang dapat berkesinambungan 
memperkuat imaji ruang yang lebih besar. Kota Bandung yang merupakan kota dengan multikultur sebagai ciri dari kota modern yang juga merupakan ibu kota propinsi Jawa Barat, memiliki karakter unik yang khas dan perlu diteliti secara mendalam untuk menghasilkan panduan yang kuat dalam membangun imaji kota yang kuat. Memahami faktor-faktor yang berpengaruh dalam masyarakat dan cara pandang yang dimiliki masyarakat dalam memahami ruang tinggalnya adalah satu metode yang perlu ditekankan dalam penciptaan dan pengolahan seluruh ruang yang akan berinteraksi dengan publiknya. Ruang tidak lagi sebatas kepemilikan wilayah kepentingan pihak-pihak tertentu dalam batasan ekonomi, sosial atau politik; namun kepentingan budaya secara garis besar harus mampu menyatukan berbagai kepentingan tersebut, dengan tidak menghilangkan kepentingan golongan, namun mampu menciptakan kesatuan imaji kota dalam wujud akhir yang kuat dan terlebih lagi, mampu menggambarkan ruang dan publik kota tersebut dengan tepat.

\section{Daftar Pustaka}

Atkins, Robert

1990 Artspeak, a guide to contemporary ideas, movements and buzzwords,
Abbeville Press Publishers, New York, USA.

Bishop, Claire

2004 Antagonism and Relational Aesthethics, MIT Journal, October, Fall 2004, ISSN 0162-2870

Bourriaud, N.

2002 Relational Aesthetic,Translated by Simon Pleasance \& Fronza Woods with the participation of Mathieu Copeland, Les Presses du Reel. Dijon, Paris

Carmona, et al.

2003 Public places - urban spaces, the dimension of urban design.

Architectural press.

2008 Public space: the management dimension. Routledge, Taylor\&Francis group. New York, USA.

Carr, S., Francis, Mark, Rivlin, Leanne G. \&Stone, Andrew M.

1992 Public Space, Cambridge University Press. Cambridge.

Lynch, Kevin

1960 The Image of The City. The Technology Press \& Harvard University Press, Cambridge. 